\title{
SEISMIC ASSESSMENT OF DUTCH URM BUILDINGS ACCORDING TO NPR9998:2018 CODE WITH AN EQUIVALENT-FRAME APPROACH
}

\author{
STEFANO BRACCHI ${ }^{1 *}$, FRANCESCO GRAZIOTTI $^{1}$, FRANCESCO MESSALI $^{2}$ AND \\ ANDREA PENNA ${ }^{1}$ \\ ${ }^{1}$ Department of Civil Engineering and Architecture (DICAr) \\ University of Pavia \\ Via Ferrata 3, 27100 Pavia, Italy \\ e-mail: stefano.bracchi@unipv.it (*corresponding author), francesco.graziotti@unipv.it, \\ andrea.penna@unipv.it, http://dicar.unipv.it/ \\ ${ }^{2}$ Department of Materials, Mechanics, Management \& Design \\ Technical University of Delft \\ Stevinweg 1, Delft, Netherlands \\ e-mail: f.messali@tudelft.nl, http://www.tudelft.nl/en/ceg/about-faculty/departments/materials- \\ mechanics-management-design-3md/
}

Keywords: Equivalent-Frame, Seismic Assessment, Induced Seismicity, Pushover Analysis, Numerical Modelling

\begin{abstract}
In the last two decades, the province of Groningen, located in the North-East of the Netherlands, has been subjected to an increasing number of earthquakes induced by gas extractions. The existing building stock is mainly composed by unreinforced masonry (URM) buildings not conceived to resist seismic loads. The need of reducing the vulnerability of these buildings by means of retrofit interventions, led to the development and adoption of a new guideline (NPR9998:2018). As regards the seismic assessment of URM buildings using nonlinear static analysis, the guideline includes significant differences with respect to Eurocode 8, which is adopted in other European countries. The more significant differences lay in the description of failure mechanisms and constitutive laws of piers and spandrels, in the identification of limit states and in the calculation of seismic demand. In the last years, the assessment and retrofit in the region has been carried out using software based on an equivalent-frame strategy: among these, the 3Muri software has been widely adopted. The solver of this program is the research software TREMURI. In this work, a new version of the solver adopted by the software 3Muri, complying with the requirements of the new Dutch guideline, was developed; the tool was then validated with simple examples. To illustrate the specificities of the new guideline, the seismic assessment of a building representative of one of the most widely diffused URM building typologies in the area was performed.
\end{abstract}

\section{INTRODUCTION}

In the last decades the province of Groningen, located in the North-East Netherlands, has been subjected to earthquakes induced by reservoir depletion due to gas extraction. The 
existing building stock is not designed to resist seismic loads and it is mainly composed by unreinforced masonry (URM) buildings. To study the seismic response of construction typologies similar to those of the Dutch practice, an experimental campaign has been recently carried out. Among the various tests, a significant number of shake-table tests were performed at the EUCENTRE laboratory on buildings representative of the most vulnerable and diffused URM building typologies of the area [1].

In the meantime, Dutch engineering companies have been performing the seismic assessment of residential buildings in the Groningen area. For the weaker structures, they have also been performing structural retrofit to improve the seismic performance. To this aim, several guidelines were developed by the regulator, starting from the guideline NPR9998:2015 [2], followed by NPR9998:2017 [3], up to the most recent NPR9998:2018 [4]. The last two codes were written accounting for the results of recent research in the field of seismic assessment of buildings; prescriptions regarding the global and local assessment are described in Annex $\mathrm{G}$ and $\mathrm{H}$, respectively. The various documents contain significant differences with respect to the official European seismic code Eurocode 8-Part 1 [5] and 3 [6].

To perform the assessment, the engineers mainly use nonlinear static analyses carried out with models based on an equivalent-frame discretization of the building, which is a widely adopted technique for URM ([7],[8],[9]). The opportunity of performing the seismic assessment of URM buildings with pushover analysis was considered in the first guideline NPR9998:2015, but no specific recommendations were provided, and the analyst had to refer to Eurocode 8-Part 1. On the opposite, the last version NPR9998:2018 contains specific recommendations for software used by the NPR 9998:2015, whereas it needs some changes This paper firstly identifie the specificitie

2018 in the followings). Then, a new version of the TREMURI research program [11] was

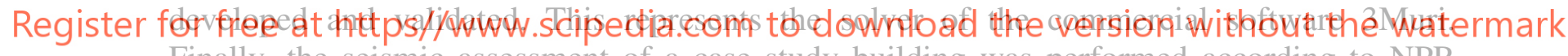
Finally, the seismic assessment of a case study building was performed according to NPR 2018. This work focuses on global analysis only, i.e. local verifications are not considered.

\section{SPECIFICITIES OF THE DUTCH PRACTICE GUIDELINE NPR9998:2018}

As a first step, the differences between NPR 2018 and Eurocode 8 were identified, limiting the study to the aspects relevant for the assessment of URM building by means of nonlinear static analysis using equivalent-frame models. The main differences regard the constitutive laws of the structural elements and the identification of displacement demand and capacity.

\subsection{Constitutive laws of the structural elements}

As regards piers, NPR 2018 defines three mechanisms: flexural and shear associated with failure of masonry or with sliding along a damp proof course membrane DPCM. The strength associated with the flexural mechanism $V_{p}$ is:

$$
V_{p}=F \frac{l_{\text {penant }}}{2 h_{0}}\left(1-1.15 \frac{\sigma_{y}}{f_{\text {ma } ; m}}\right)
$$


where $F$ is the axial load acting on the critical cross-section, $l_{\text {penant }}$ is the length of the pier, $h_{0}$ is the distance between the section where the flexural strength is reached and the inflection point, $\sigma_{y}$ is the average compressive stress on the full cross-section and $f_{m a ; m}$ is the compressive strength of masonry. The strength of the pier is the minimum between the one calculated at the top and bottom section of the pier.

The rocking of a pier is limited by the crushing failure of masonry attained at the toes. This mechanism is taken into account limiting the displacement capacity of the flexural mechanism. In particular, the drift limit for the near collapse (NC) limit state $\theta_{N C}$ is:

$$
\theta_{N C}=0.0135\left(1-2.6 \frac{\sigma_{y}}{f_{\text {ma } ; m}}\right) \frac{h_{\text {ref }}}{h_{\text {penant }}} \sqrt{\frac{h_{\text {penant }}}{l_{\text {penant }}}}
$$

where $\sigma_{y}$ is the average compressive stress at the base of the pier on the full cross-section, $h_{\text {penant }}$ is the height of the pier (in $\mathrm{m}$ ) and $h_{\text {ref }}$ is the reference height $(2.4 \mathrm{~m})$. No indication is given in NPR 2018 for the severe damage (SD) limit state; for consistency with the previous guideline, the drift capacity is assumed to be equal to $75 \%$ of the drift capacity at NC.

The constitutive force/drift law is bilinear with an elastic branch up to the yielding drift $\theta_{y}$ followed by a constant branch up to the drift corresponding to NC (Figure 1).

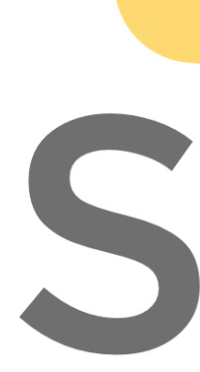

$V$
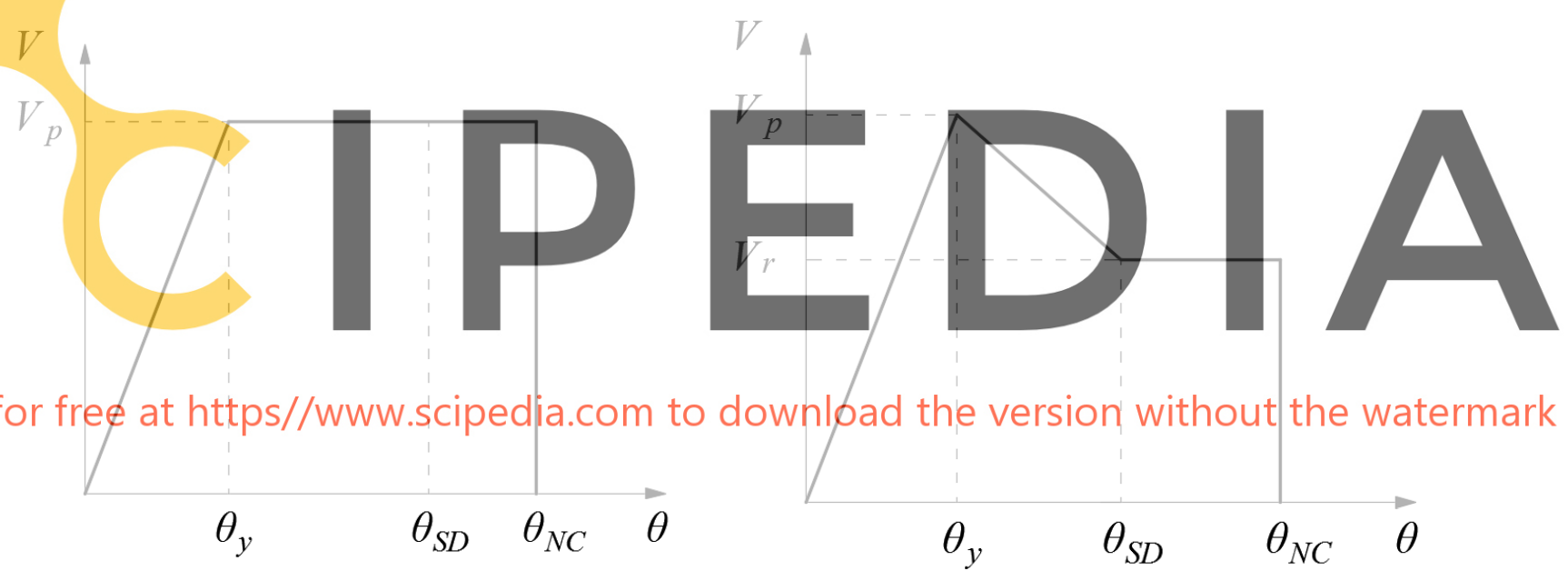

Figure 1: Capacity curve of a pier: flexural (left) and shear for failure of masonry (right) mechanism

The constitutive force/drift law associated with the shear mechanism of failure of masonry is piece-wise linear, with a peak strength followed by a linear decay up to the residual strength (Figure 1). The peak strength $V_{p}$ is the minimum of the shear strength calculated at the two ends of the element, each one with its axial load. At each end, the strength is given by:

$$
V_{p}=\min \left\{V_{p, 1}, V_{p, 2}\right\}
$$

where

$$
\begin{gathered}
V_{p, 1}=l_{C} t_{\text {penant }}\left(f_{m a ; ; ; 0 ; m}+\mu_{m a ; m} \sigma_{y}\right) \\
V_{p, 2}=0.1 f_{b} l_{C} t_{\text {penant }}
\end{gathered}
$$


where $l_{C}$ is the length of the compressed part of the section, $f_{m a ; v ; 0 ; m}$ is the initial average shear strength of masonry, $\mu_{m a ; m}$ is the average friction coefficient, $\sigma_{y}$ is the average compressive stress in the compressed part of the section, $f_{b}$ is the normalized average compressive strength of bricks in the load direction and $t_{\text {penant }}$ is the thickness of the pier. Eq. (4) is associated with stepped cracks through the mortar joints, whereas Eq. (5) with cracks through the bricks. Moreover, the length of the compressed part of the section cannot exceed a maximum value equal to the length of the section, and a minimum value corresponding to a rectangular stress block idealization of the compressive stress profile. For solid clay bricks NPR 2018 suggests that the value of $f_{b}$ is generally at least $20 \mathrm{MPa}$. In case of calcium-silicate bricks and blocks, the value of $f_{b}$ is at least $12 \mathrm{MPa}$, whereas for calcium-silicate elements $f_{b}$ is at least equal to $15 \mathrm{MPa}$.

The residual shear strength is equal to:

$$
V_{r}=\min \left\{l_{C} t_{\text {penan }} \mu_{m a ; m} \sigma_{y} ; 0.1 f_{b} l_{C} t_{\text {penant }}\right\}
$$

The drift capacity at $\mathrm{NC} \theta_{N C}$ is equal to $0.75 \%$ in case Eq. (4) governs and to the $\theta_{N C}$ of flexural mechanism (Eq. (2)) in case Eq. (5) governs. The drift capacity at SD $\theta_{S D}$ is equal to $0.3 \%$ in case Eq. (4) governs and to $75 \%$ of $\theta_{N C}$ in case Eq. (5) governs, in analogy with the flexural failure mode (even if NPR 2018 does not give indications for this last case).

In case a damp proof course membrane is present, it forms a potential slip surface that can limit the shear strength of a pier. The strength associated with this slip-plane failure mechanism is:
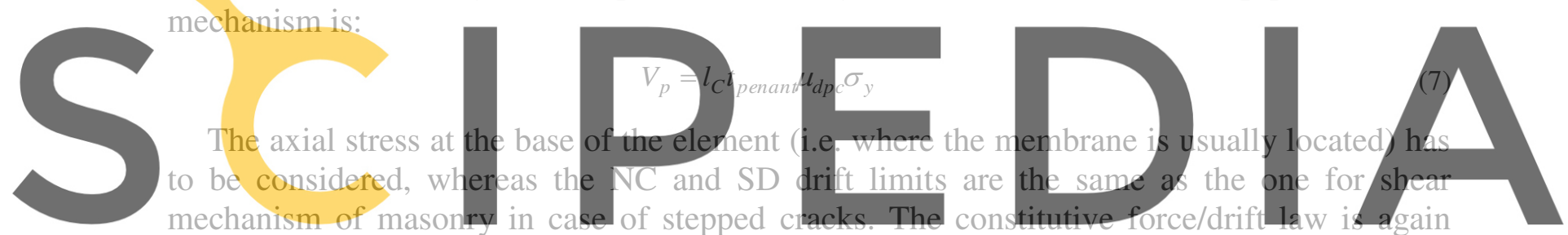

bilinear (Figure 2). The shear mechanism is attributed to the pier based on the minimum peak

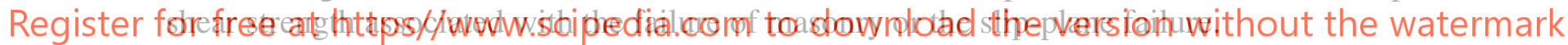

As regards spandrels, NPR 2018 defines two mechanisms: flexural and shear mechanism.

In both the cases, the constitutive force/drift law is piece-wise linear, characterized by a peak and a residual strength (Figure 2).

The peak flexural capacity of spandrels $V_{p}$ is given by:

$$
V_{p}=\left(f_{t}+\sigma_{\text {borstw }}\right) \frac{h_{\text {borstw }}^{2} b_{\text {borstw }}}{3 l_{\text {borstw }}}
$$

where $f_{t}$ is the equivalent tensile strength of the spandrel, $\sigma_{b o r s t w}$ is the axial stress in the spandrel assuming a uniform stress distribution, $h_{\text {borstw }}$ is the height, $b_{\text {borstw }}$ is the thickness and $l_{\text {borstw }}$ is the length of the spandrel. Unless the spandrel is pretensioned, it is assumed that the axial load in the spandrel is negligible when determining the peak shear strength. The equivalent tensile strength of the spandrel $f_{t}$ is calculated as:

$$
f_{t}=1.3\left(f_{m a ; b ; p e r}+0.5 \mu_{m a ; m} \frac{\sigma_{p, l e f t}+\sigma_{p, r i g h t}}{2}\right)+\frac{f_{m a ; b ; p e r}}{2 \mu_{m a ; m}}
$$

where $f_{m a ; b ; p e r}$ is the bonding strength of the joint of masonry (equal to the cohesion $f_{m a ; v ; 0 ; m}$, as 
specified in NPR 2018), $\mu_{m a ; m}$ is the average friction coefficient of masonry, $\sigma_{p, l e f t / r i g h t}$ is the axial stress in the left/right pier adjacent to the spandrel.

When lintels are sufficiently anchored into the piers, the lintel contribution to the residual flexural capacity of the spandrel should be considered. The residual flexural strength $V_{r}$ can be estimated as:

$$
V_{r}=\frac{\sigma_{\text {borstw }} h_{\text {borstw }}^{2} b_{\text {borstw }}}{l_{\text {borstw }}}\left(1-\frac{\sigma_{\text {borstw }}}{0.85 f_{h ; m}}\right) \leq V_{p}
$$

where $f_{h ; m}$ is the compressive strength of masonry in the horizontal direction (equal to 0.5 $\left.f_{m a ; m}\right)$ and $V_{p}$ is the minimum between the peak flexural and shear strength of the spandrel. The axial stress in the spandrel should be taken into account when calculating the residual strength; an upper bound estimate of the axial stress $\sigma_{b o r s t w}$ in a restrained spandrel can be determined as:

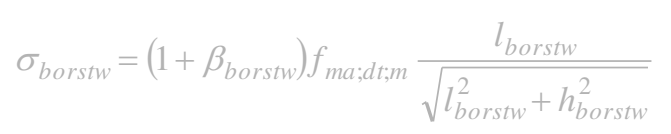

where $\beta_{b o r s t w}$ is the shear stress factor depending on the geometry of the spandrel and $f_{m a ; d t ;}$ is the diagonal strength of masonry.

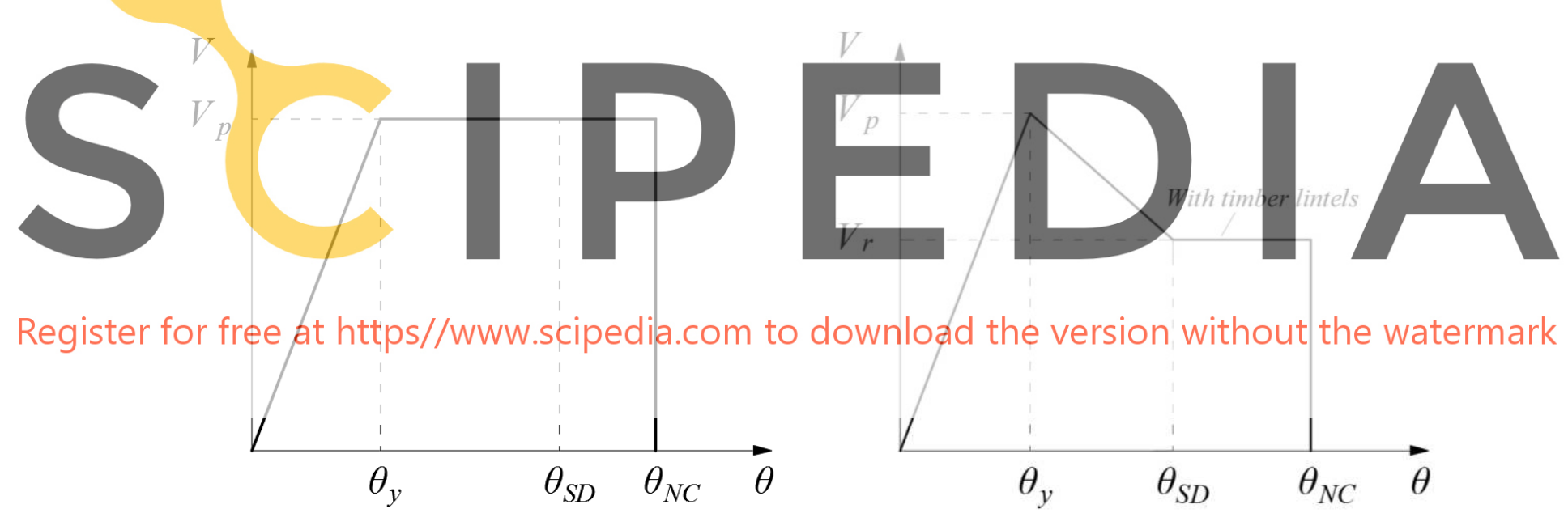

Figure 2: Capacity curve of a pier with slip-plane failure mechanism (left) and capacity curve of a spandrel with flexural and shear mechanism (right)

The peak shear strength of a spandrel $V_{p}$ can be estimated as the minimum between the ones associated with two mechanisms: formation of cracks through head- and bed-joints over almost the entire height of the spandrel (Eq. (12)) and cracks in the bricks (Eq. (13)). The first mechanism takes place when mortar is weaker than bricks, whereas the second one corresponds to the case of weaker bricks. Timber lintels do not give a significant contribution to the peak shear capacity of URM spandrels and therefore they can be ignored.

$$
V_{p}=\frac{2}{3}\left(f_{m a ; b ; p e r}+\mu_{m a ; m} \sigma_{b o r s t w}\right) h_{b o r s t w} b_{b o r s t w}
$$




$$
V_{p}=f_{m a ; d t ; m} \beta_{b o r s t w} \sqrt{1+\frac{\sigma_{\text {borstw }}}{f_{\text {ma;dt;m }}}} h_{\text {borstw }} b_{\text {borstw }}
$$

When lintels are sufficiently anchored into the piers, the lintel contribution to the residual shear capacity of the spandrel should be considered and the residual shear strength is calculated with Eq. (10).

The drift limits for spandrels are common for both flexural and shear mechanism. The drift capacity at $\mathrm{NC}$ is equal to $4 \theta_{y}$, where $\theta_{y}$ is the yielding drift, whereas the drift capacity at SD is equal to $3 \theta_{y}$.

\subsection{Global displacement demand and capacity}

As regards the definition of displacement capacity and demand of the global analysis, the new aspects of NPR 2018 consist in the definition of the equivalent single degree of freedom (SDOF) system, of the equivalent bilinear curve and the adoption of the capacity spectrum method to compute the displacement demand. In particular, the single degree of freedom (SDOF) system equivalent to the building is defined as:
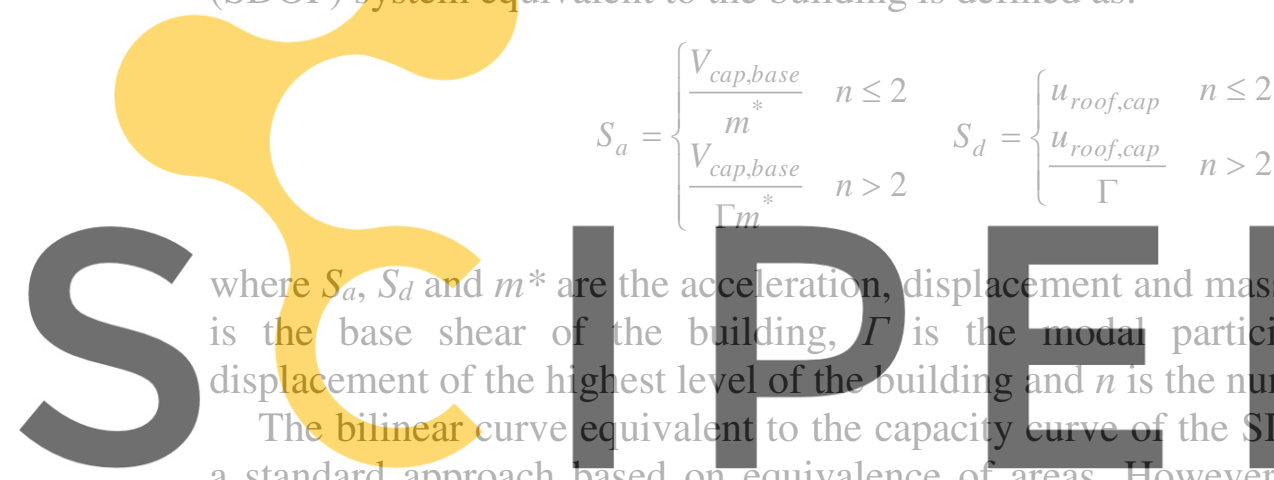

(14)

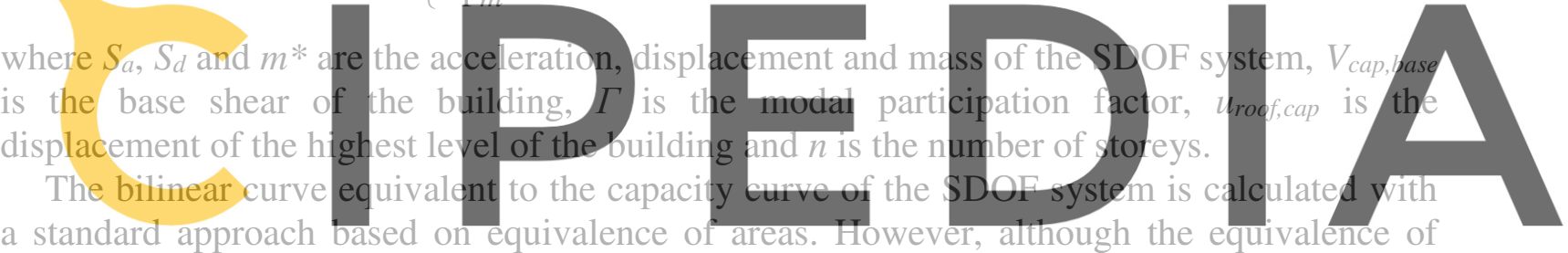
area is performed up to the displacement corresponding to the $20 \%$ decay of the base strength,

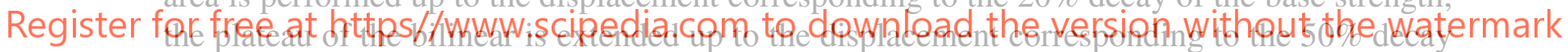

of the base shear, which represents the global displacement capacity at NC. To account for

soil-structure interaction, NPR 2018 suggests to increase the displacement of the SDOF system (obtained from an analysis with fixed foundations), as a function of the acceleration of the SDOF system.

As regards the calculation of the displacement demand, NPR 2018 suggests the use of an iterative capacity spectrum method with over-damped spectra, discouraging, although not precluding, other methods (e.g. N2 [12]). The iterative capacity spectrum method of NPR 2018 consists of firstly determining the global ductility of the equivalent SDOF system, $\mu_{s y s}$, calculated as $u_{\text {duct,sys }} / u_{y ; s y s}$, where $u_{\text {duct,sys }}$ is the minimum between the displacement capacity $\left(u_{\text {cap;sys }}\right)$ and the displacement corresponding to the intersection of the bilinear capacity curve and the spectrum in $S_{a}$ vs. $S_{d}$ format and $u_{y ; s y s}$ is the yield displacement of the SDOF system.

Secondly, the hysteretic damping of the system $\xi_{\text {hys }}$ has to be calculated as:

$$
\xi_{\text {hys }}=0.42\left(1-\frac{0.9}{\sqrt{\mu_{s y s}}}-0.1 \sqrt{\mu_{s y s}}\right) \leq 0.15
$$

where $\xi_{\text {hys }}=0.15$ for $\mu_{\text {sys }}>4$, followed by the determination of the total damping $\left(\xi_{\text {sys }}=\right.$ 
$\left.\xi_{0}+\xi_{\text {hys }}+\beta_{0} \leq 0.4\right)$, where $\beta_{0}$ is the contribution due to the soil. The reduction factor of the spectrum can then be obtained as:

$$
\eta_{\xi}=\sqrt{\frac{7}{2+\xi_{s y s}}} \geq 0.55
$$

With the new ductility $\mu_{s y s}$, iterations can be performed until the initial and final ductilities are similar. The displacement demand is the intersection between the bilinear and the reduced spectrum. Figure 3 shows the application of the iterative capacity spectrum method.

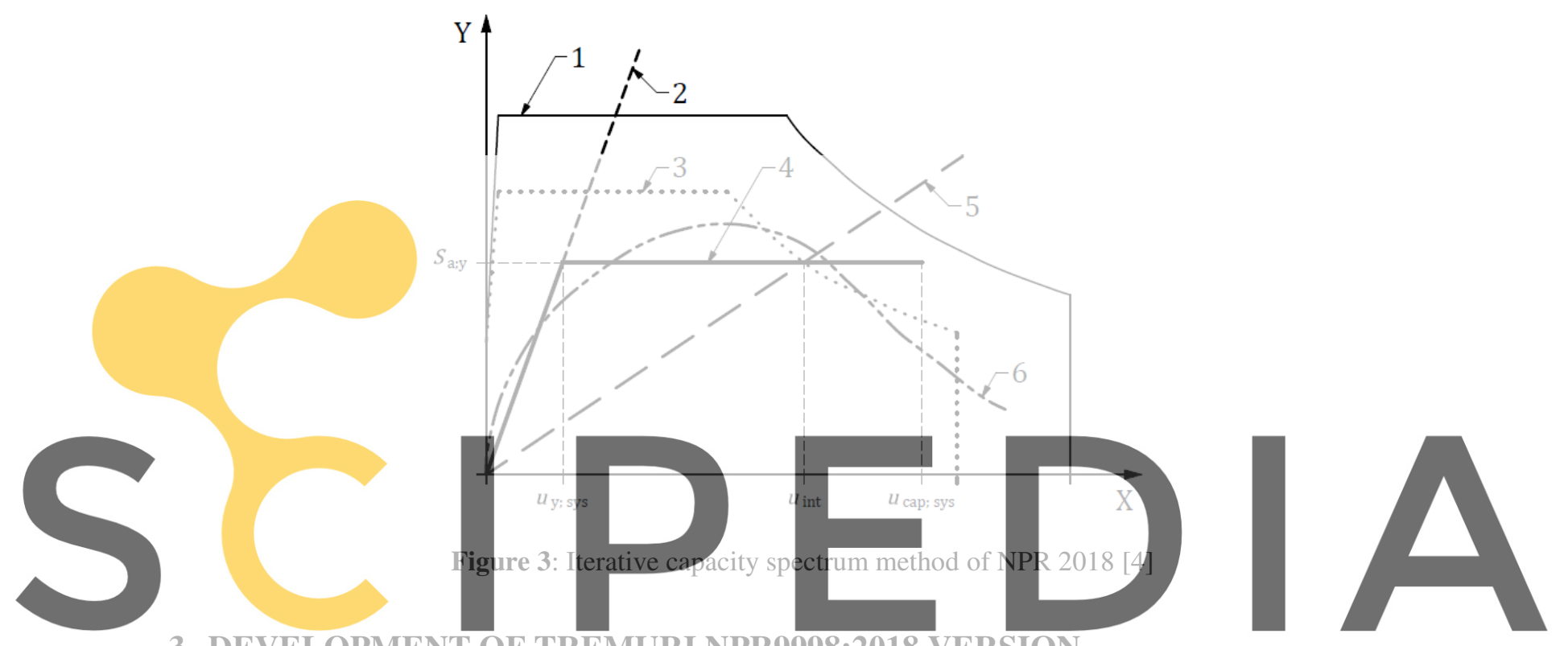

\section{DEVELOPMENT OF TREMURI NPR9998:2018 VERSION}

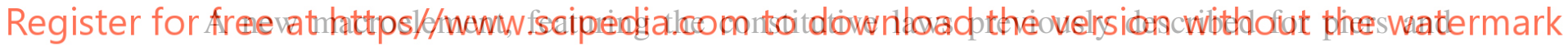
spandrels was developed and implemented in the TREMURI software. To test the efficiency of the new element in reproducing the code force/drift laws, a series of nonlinear analyses in displacement control were performed. In the case of single piers, a monotonically increasing horizontal displacement was applied to the top of the element, whereas in the case of single spandrels a vertical displacement was applied. Figure 4 and Figure 5 show the results of the analyses in terms of force vs. drift curves and damage patterns for piers and spandrels, respectively. In the damage pattern representation, different colors indicate different damage mechanisms, whereas different markers identifies the level of damage (plastic, SD, NC) of the element.

The new element was also implemented in the commercial software 3Muri [10], together with the automatic calculation of displacement demand and capacity as described in the previous section. This would allow engineers to perform the seismic assessment and retrofit according to the considered guideline.

In the following, the seismic assessment was performed obtaining the global pushover curve using the software TREMURI and calculating the seismic demand and capacity according to NPR 2018 using properly developed tools external to TREMURI and 3Muri. 


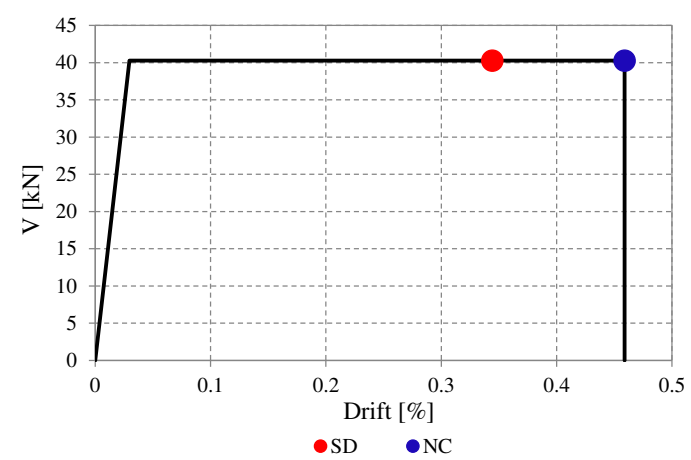

Flexure

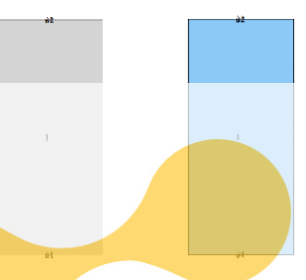

Flex.

Undam.

Plastic

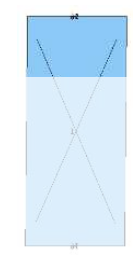

Flex.

SD

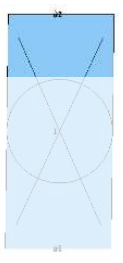

Flex.

$\mathrm{NC}$
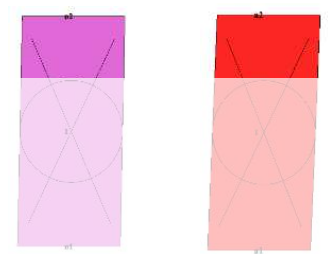

Shear - joints
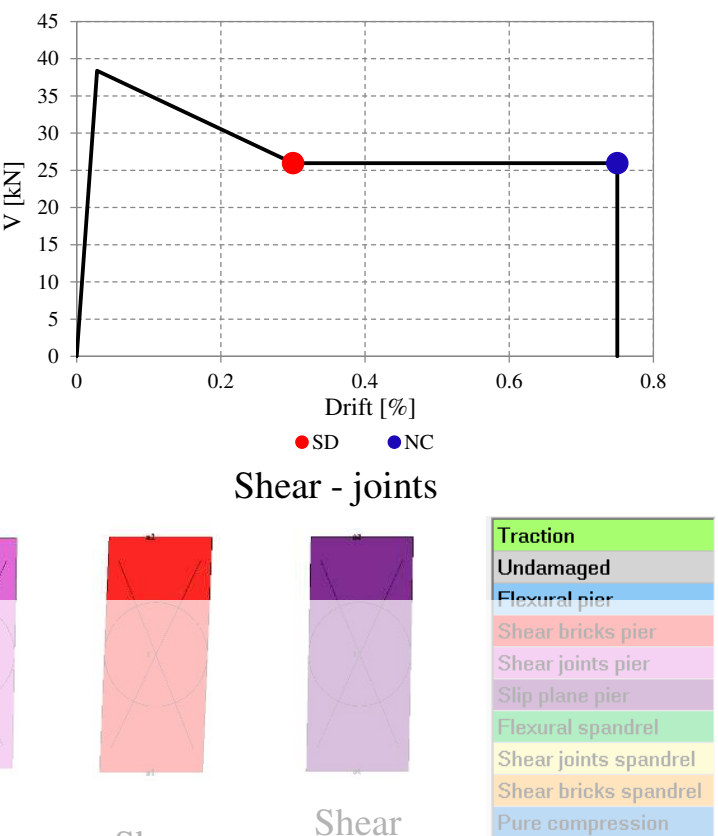

Shear

Shear

Shear joints NC bricks NC slip-plane NC

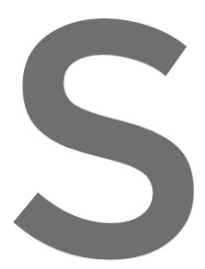

Figure 4: Force vs.
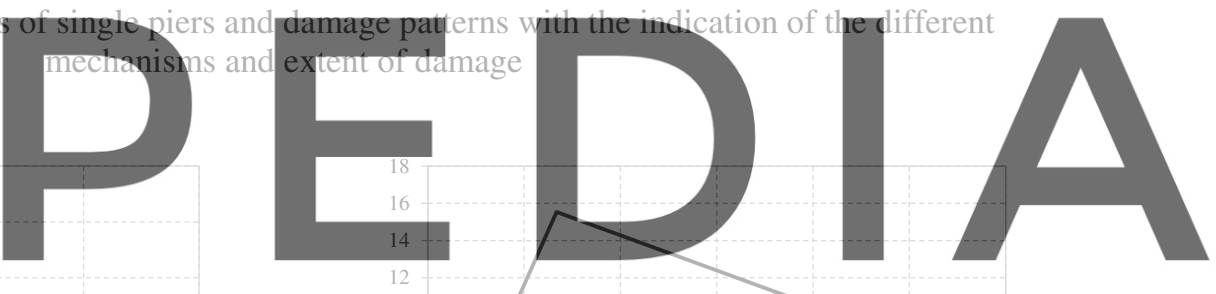

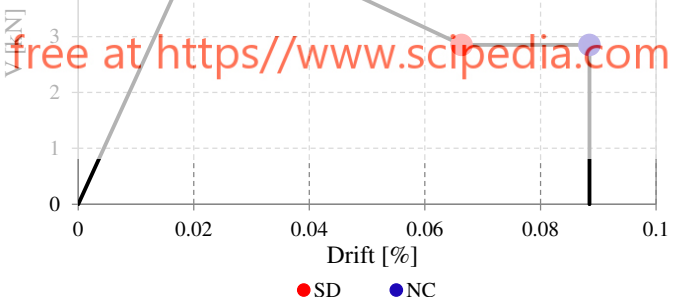

Flexure

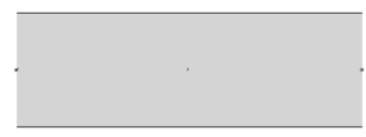

Flex. Undam.

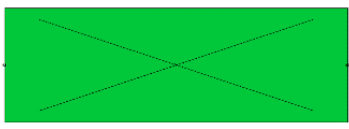

Flex. SD

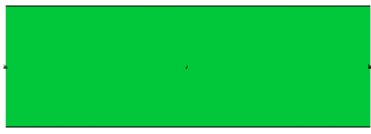

Flex. Plastic

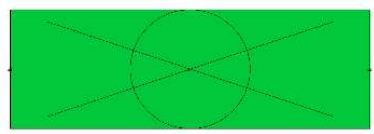

Flex. NC

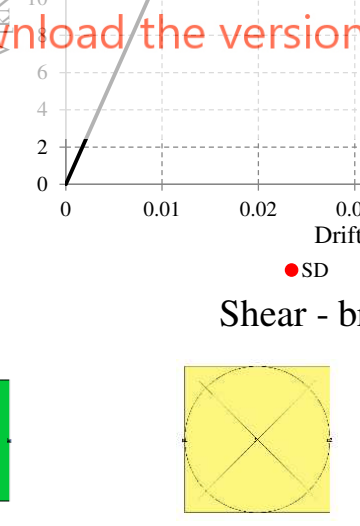

Shear joints NC

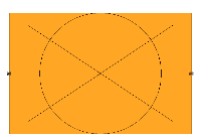

Shear bricks NC

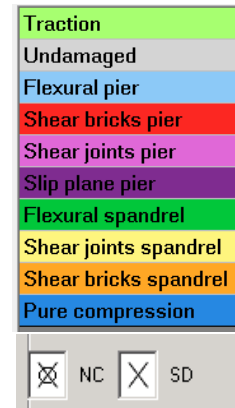

$\bar{\bigotimes}_{N C} \bar{X}_{S D}$

Figure 5: Force vs. drift curves of single spandrels and damage patterns with the indication of the different mechanisms and extent of damage 


\section{EXAMPLE OF GLOBAL SEISMIC ASSESSMENT ACCORDING TO NPR9998:2018}

A simple case study building representative of one of the typologies of the building stock of the Groningen area was selected (Figure 6). The specimen tested by [13] on the shake-table of the EUCENTRE laboratory was considered: it is the end-unit of a terraced house building with cavity walls, which is one of the most vulnerable building typologies of the area. The structure is characterized by a weak direction (the one parallel to the openings) and a strong direction characterized by no openings. In developing the TREMURI model of the case study, a series of simplifying assumptions were performed in order to simulate the model built by a professional engineer in charge of the assessment (e.g. roof and external leaves of cavity walls modelled as additional masses only).
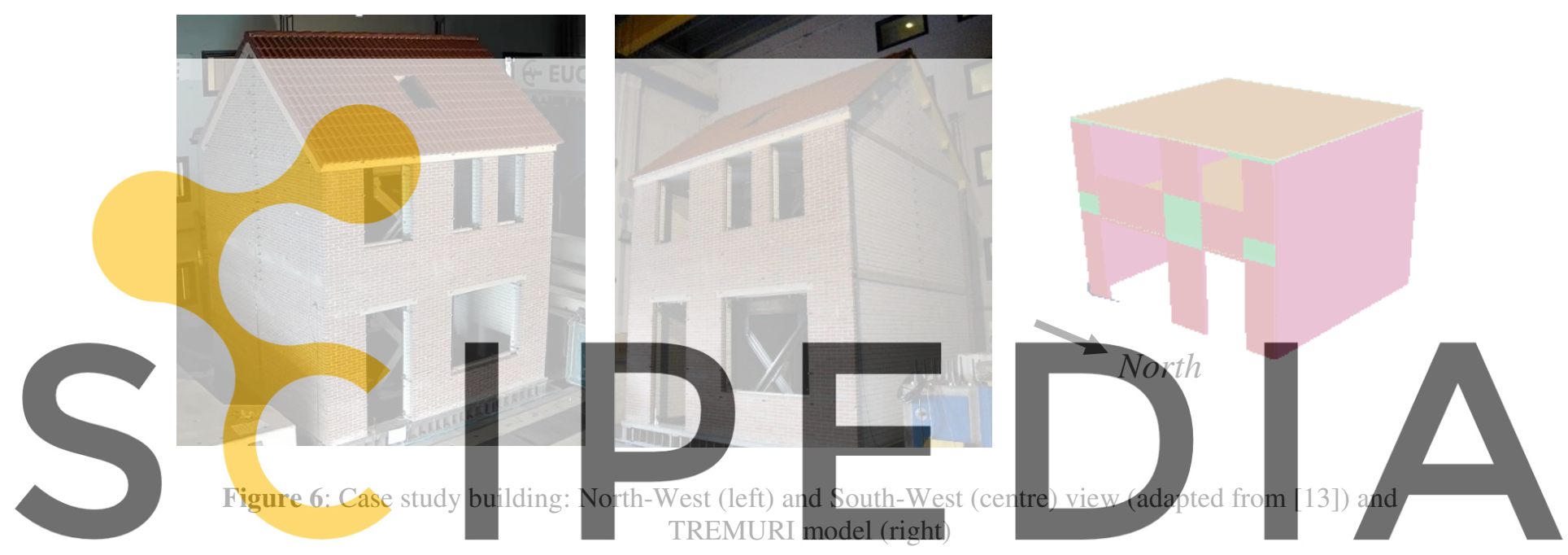

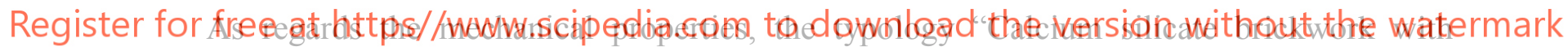
general purpose mortar (1960-present)" described in NPR 2018 was considered. Material properties of the clay leaf were not considered, since this was modelled as additional mass only. The elastic moduli $E$ and $G$ were reduced by a factor 2 to account for cracked stiffness.

Table 1 reports the values of mechanical properties used in this study. Moreover, damp proof courses were assumed not to be present; therefore, the slip-plane failure mechanism was not considered. Floors were assumed to be rigid, with $100 \%$ of the acting load assigned to the walls orthogonal to the spanning direction and $0 \%$ to the walls parallel to it.

Table 1: Values of mechanical properties

\begin{tabular}{ccccccc}
\hline $\begin{array}{c}E \\
{[\mathrm{MPa}]}\end{array}$ & $\begin{array}{c}G \\
{[\mathrm{MPa}]}\end{array}$ & $\begin{array}{c}\rho \\
{\left[\mathrm{kg} / \mathrm{m}^{3}\right]}\end{array}$ & $\begin{array}{c}f_{m} \\
{[\mathrm{MPa}]}\end{array}$ & $\begin{array}{c}f_{v 0} \\
{[\mathrm{MPa}]}\end{array}$ & $\begin{array}{c}\mu \\
{[-]}\end{array}$ & $\begin{array}{c}f_{b} \\
{[\mathrm{MPa}]}\end{array}$ \\
\hline 2000 & 825 & 1834 & 7 & 0.25 & 0.6 & 12 \\
\hline
\end{tabular}

When performing the assessment, soil-structure interaction was considered, whereas the soil damping was neglected. The demand was maintained fixed and corresponded to the spectrum of the village of Loppersum, obtained from [14] for a return period of 2475 years, 
corresponding to near collapse limit state (with $a_{g} S=0.1976 \mathrm{~g}, p=1.919, T_{b}=0.154 \mathrm{~s}, T_{c}=$ $\left.0.664 \mathrm{~s}, T_{d}=0.909 \mathrm{~s}, \eta_{e l}=1\right)$. A more detailed study on the demand is reported in [15].

Figure 7 shows the pushover curve and damage patterns obtained with the TREMURI element consistent with NPR 2018 for a selected analysis in the weak direction, compared to the ones obtained with the Eurocode 8 element. From the damage patterns, it can be noticed that NPR 2018 is predicting a shear behavior (attainment of shear strength of bricks) in some elements with damage concentrated in the piers at the ground level. On the contrary, Eurocode 8 predicts a flexural mechanism, again with damage concentrated in the piers at the ground level. However, the displacement capacity obtained according to NPR 2018 tends to be higher, due to the formulation adopted for the element drift limit at near collapse (NC) limit state.
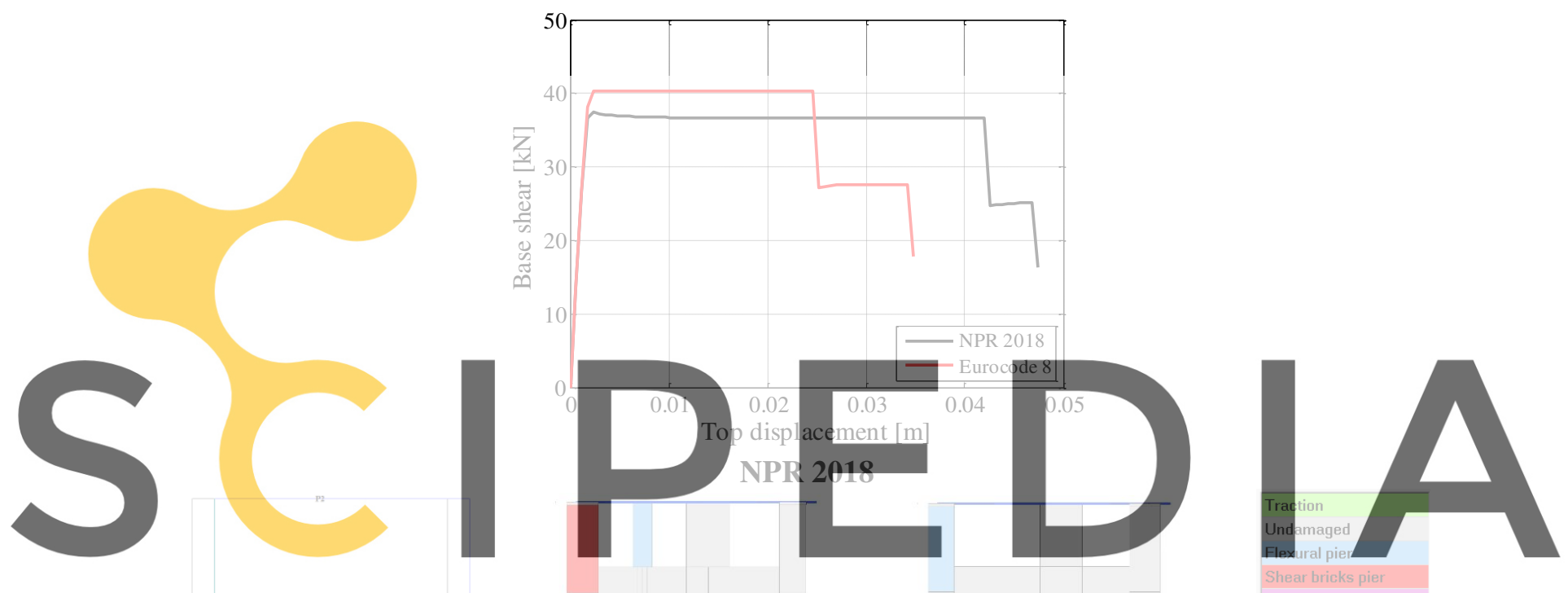

Register for free at https//www.scipedia.com to download the version without the watermark

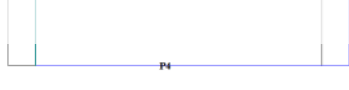

Plan

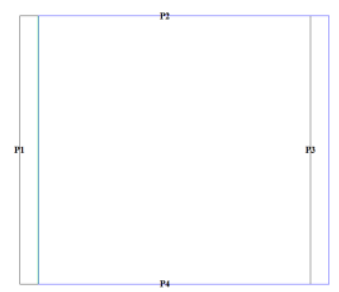

Plan

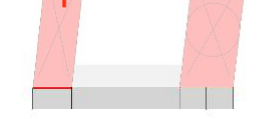

West wall

\section{Eurocode 8}

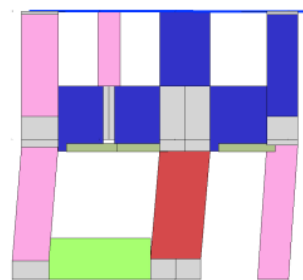

West wall

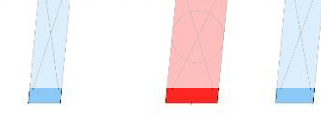

East wall
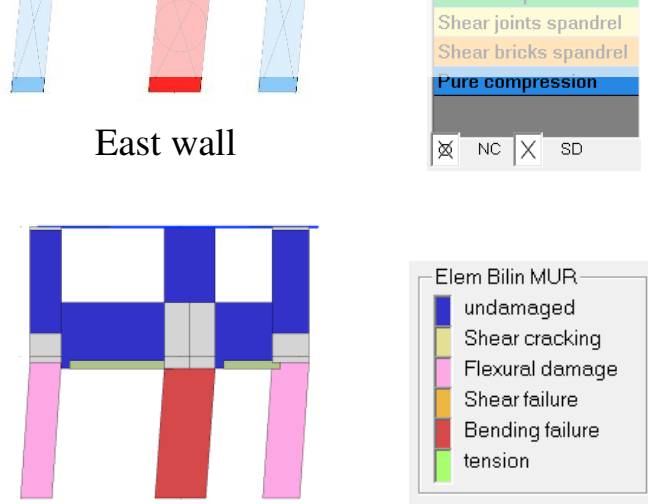

East wall

Figure 7: Pushover curve, plan deformed shape and damage patterns according to NPR 2018 and Eurocode 8 in the weak direction - inverse triangular distribution of forces, positive verse, no eccentricity

Figure 8 shows the results of the assessment according to NPR 2018 for the considered direction with reference to the critical analysis (i.e. the one with a mass proportional 
distribution of forces, applied in the negative direction and with positive eccentricity). The building is verified, although in the nonlinear branch of the bilinear curve, as also confirmed by the large amount of reduction of the demand spectrum in the capacity spectrum method.

$$
\begin{gathered}
d_{\text {dem }} / d_{\text {cap }}=0.68 \\
d_{\text {SDOF,dem }}=32 \mathrm{~mm}
\end{gathered}
$$

Safety check: verified

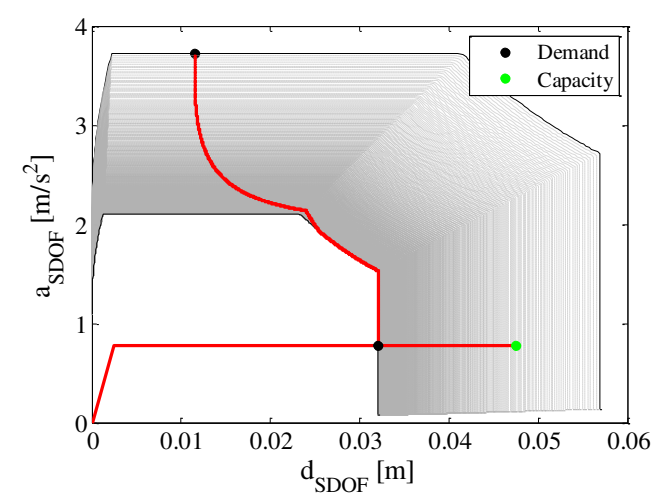

Figure 8: Results of the safety check according to NPR 2018 in the weak direction for the critical analysis

\section{CONCLUSIONS}

This paper presents the results of the seismic assessment of URM buildings performed according to the Dutch practice guideline NPR9998:2018 by means of nonlinear static analysis with an equivalent-frame model. Firstly, the main new aspects of the guideline with respect to Eurocode 8 were identified: these consist in the constitutive laws of the single elements (piers and spandrels), in the definition of the equivalent SDOF system and in the adoption of the capacity spectrum method in the calculation of the seismic demand. Secondly, a new macroelement including all the constitutive laws depending on the various failure mechanisms was developed and implemented in the TREMURI research software. This allows the performance of nonlinear static analyses according to the considered guideline. Finally, the seismic assessment of a case study building was performed. After the calculation of the capacity curve, the seismic demand and capacities were calculated according to NPR 2018, adopting a seismic action consistent with the seismicity of the area.

The whole assessment procedure, from the definition of the capacity curve to the calculation of displacement capacity and demand by means of the capacity spectrum method was then implemented in the commercial software 3 Muri. The goal of the work is to provide engineers with a simple software fully compliant with the adopted guideline to perform the seismic assessment and retrofit of URM buildings.

Acknowledgements. The work presented in this paper was carried out within the activities of two TU Delft-University of Pavia 2018-2019 projects, funded by Nationaal Coordinator Groningen NCG, Centrum Veiling Wonen CVW and Econstruct BV. However, opinions and conclusions do not necessarily reflect those of the funding entities. The authors would like to particularly thank Wim Meilink for his help and suggestions in the various phases of the projects.

\section{REFERENCES}

[1] Graziotti, F., Penna, A. and Magenes, G. A comprehensive in situ and laboratory testing 
programme supporting seismic risk analysis of URM buildings subjected to induced earthquakes. Bull. Earthq. Eng. (2019) 17:4575-4599.

[2] Nederlands Normalisatie Instituut (NEN), NPR 9998:2015. Beoordeling van de constructieve veiligheid van een gebouw bij nieuwbouw, verbouw en afkeuren Grondslagen voor aardbevingsbelastingen: geïnduceerde aardbevingen. Assessment of buildings in case of erection, reconstruction and disapproval - Basic rules for seismic actions: induced earthquakes (2015) (in Dutch).

[3] Nederlands Normalisatie Instituut (NEN), NPR 9998:2017. Beoordeling van de constructieve veiligheid van een gebouw bij nieuwbouw, verbouw en afkeuren Grondslagen voor aardbevingsbelastingen: geïnduceerde aardbevingen. Assessment of structural safety of buildings in case of erection, reconstruction and disapproval - Basic rules for seismic actions: induced earthquakes (2017) (partially in Dutch).

[4] Nederlands Normalisatie Instituut (NEN), NPR 9998:2018. Beoordeling van de constructieve veiligheid van een gebouw bij nieuwbouw, verbouw enafkeuren Geïnduceerde aardbevingen - Grondslagen, belastingen en weerstanden. Assessment of structural safety of buildings in case of erection, reconstruction and disapproval - Induced earthquakes - Basis of design, actions and resistances (2018) (in Dutch).

[5] CEN, European Committee for Standardisation, Eurocode 8: Design of structures for earthquake resistance - Part 1: General rules, seismic actions and rules for buildings, Design Code EN 1998-1, Brussels, Belgium (2004).

[6] CEN, European Committee for Standardisation, Eurocode 8: Design of structures for earthquake resistance - Part 3: Strengthening and repair of buildings, Design Code EN 1998-3, Brussels, Belgium (2005).

[7] Bracchi, S., Rota, M., Penna, A. and Magenes, G. Consideration of modelling uncertainties in the seismic assessment of masonry buildings by equivalent-frame approach. Bull. Earthq. Eng. (2015) 13:3423-3448.

[8] Bracchi, S., Rota, M., Magenes, G. and Penna, A. Seismic assessment of masonry buildings accounting for limited knowledge on materials by Bayesian updating. Bull. Earthq. Eng. (2016) 14:2273-2297.

[9] Cattari, S., Camilletti, D., Lagomarsino, S., Bracchi, S., Rota, M. and Penna, A. Masonry Italian code-conforming buildings. Part 2: nonlinear modelling and time-history analysis. J. Earthq. Eng. (2018) 22:2010-2040.

[10] STADATA, “3Muri User manual. Version: 11.4.0”, [www.stadata.com].

[11] Lagomarsino, S., Penna, A., Galasco, A. and Cattari, S. TREMURI program: an equivalent frame model for the nonlinear seismic analysis of masonry buildings. Eng. Struct. (2013) 56:1787-1799.

[12] Fajfar, P. A nonlinear analysis method for performance-based seismic design. Earthq. Spectra (2000) 16:573-592.

[13] Graziotti, F., Tomassetti, U., Kallioras, S., Penna, A. and Magenes, G. Shaking table test on a full scale URM cavity wall building. Bull. Earthq. Eng. (2017) 15:5329-5364.

[14] http://seismischekrachten.nen.nl/webtool.php.

[15] Kallioras, S., Guerrini, G., Bracchi, S., Penna, A. and Graziotti, F. Displacement demand equations for the non-linear static analysis of short-period masonry structures. $13^{\text {th }}$ North American Masonry Conference, Salt Lake City, USA (2019). 